\title{
Association of Cellulytic Enzyme Activities in Eucalyptus Mulches with Biological Control of Phytophthora cinnamomi
}

\author{
A. J. Downer, J. A. Menge, and E. Pond
}

First author: University of California Cooperative Extension, 669 County Square Drive, Suite 100, Ventura 93003; and second and third authors: University of California, Department of Plant Pathology, Riverside 92521.

Accepted for publication 1 June 2001.

ABSTRACT

\begin{abstract}
Downer, A. J., Menge, J. A., and Pond, E. 2001. Association of cellulytic enzyme activities in eucalyptus mulches with biological control of Phytophthora cinnamomi. Phytopathology 91:847-855.

A series of samples were taken from mulched and unmulched trees starting at the surface of mulch or soil to a $15 \mathrm{~cm}$ soil depth, forming a vertical transect. Saprophytic fungi isolated from the soil samples on rose bengal medium and surveyed visually were most abundant in mulches and at the interface of mulch and soil $(P<0.05)$. Microbial activity as assayed by the hydrolysis of fluorescein diacetate was significantly greater in mulch layers than in soils. Cellulase and laminarinase enzyme activities were greatest in upper mulch layers and rapidly decreased in soil layers $(P<0.05)$. Enzyme activities against Phytophthora cinna-
\end{abstract}

momi cell walls were significantly greater in mulch than in soil layers. When Phytophthora cinnamomi was incubated in situ at the various transect depths, it was most frequently lysed at the interface between soil and mulch $(P<0.001)$. Roots that grew in mulch layers were significantly less infected with Phytophthora cinnamomi than roots formed in soil layers. In mulched soil, roots were commonly formed at the mulchsoil interface where Phytophthora populations were reduced, whereas roots in unmulched soil were numerous at the $7.5 \mathrm{~cm}$ depth where Phytophthora cinnamomi was prevalent. Enzyme activities were significantly and positively correlated with each other, microbial activity, and saprophytic fungal populations, but significantly and negatively correlated with Phytophthora recovery.
Avocado root rot (ARR), caused by the fungus Phytophthora cinnamomi Rands., is the most devastating avocado disease worldwide despite nearly 50 years of research on chemical, biological, and cultural control methods. The pathogen infests most avocado groves in California, resulting in multimillion-dollar crop losses each year (8). Despite development and planting of resistant rootstocks, application of fungicides, and planting on mounds, the disease still kills avocado trees. Biological control of ARR has been successful in Australia $(5,24)$, and there has been some success in California with a similar mulching system to suppress the fungus (33).

Phytophthora cinnamomi does not survive in rain forests; thus, the Australian Ashburner system of biological control was devised by an avocado grower to simulate rain forest soil conditions. Forest litter was simulated by application of thick mulch layers. The success of the system has led to its increased use of mulching in Australia. Although a microbial role for the control is implicated, no single fungus, bacterium, or actinomycete was associated with biocontrol activities, nor has control been induced by a single organism or soil transfer (10). Introduction of biocontrol fungi on various substrates enhances control of ARR in greenhouse studies, but this can be achieved with many different kinds of organisms and substrates $(7,12)$. Successful field studies of single organism biologically enhanced mulches have not been reported. It seems that a concert of microbial processes by many organisms, called general suppression by Cook and Baker (10), may be important in controlling the disease.

Organic matter and its various qualities have been associated with Phytophthora root rot control in several systems for many years $(4,5,7,12,18,20,22,33,35,46)$. Some organic matter amend-

Corresponding author: A. J. Downer; E-mail address: ajdowner@ucdavis.edu

Publication no. P-2001-0716-02R

(c) 2001 The American Phytopathological Society ing systems $(20,46)$ achieved control with ammonia, but a single definitive mechanism of controlling Phytophthora with organic matter has never been clearly established in nonammonia generating systems. Organic matter is primarily cellulose, the most common polymer in the world (17). Organic substrates host a wide diversity of fungi and bacteria that use cellulose as a carbon source and are potent cellulase producers (49). Because cellulose is a component of Oomycete cell walls, cellulosic mulches with high cellulase activities may be harmful to the ARR pathogen.

This paper describes the distribution of microbial activity observed in mulches prepared from freshly chipped eucalyptus trimmings and underlying soil layers. We have measured the effects of mulch on microbial processes of underlying soil layers, populations of Phytophthora, and effects on the avocado root system. A mechanism of biological control related to soil enzyme activities is postulated.

\section{MATERIALS AND METHODS}

Field plot. The study was conducted on samples of soil and mulch recovered from a commercial 2-year-old avocado (Persea americana Mill.) grove replanted (immediately after removal of diseased trees) with 'Hass' scions on 'Thomas' rootstocks in the spring of 1994. The grove previously planted on Phytophthora cinnamomi-susceptible rootstocks died from ARR and had been removed. The soil was a Sorrento, silty clay loam, heavy variant (fine, montmorillonitic, thermic, Entic Haploxerolls) located in Somis, CA. Replanted trees were mulched annually during the summer with freshly chipped trimmings, Eucalyptus globulus Labil. Trimmings were applied in a 2-m-diameter circle, $15 \mathrm{~cm}$ deep around the base of each tree. The eucalyptus trimmings were branches up to $10 \mathrm{~cm}$ in diameter, including all leaves, fruit, and bark. The mulch chips were 4 to $8 \mathrm{~cm}$ long pieces and included whole or partially chopped leaves and stems (bulk density: $0.186 \mathrm{~g} / \mathrm{cm}^{3}$ ) with the following chemical characteristics: $\mathrm{pH} 5.3$; 
EC, $1.25 \mathrm{dS} / \mathrm{m} ; 46.1 \%$ total carbon (wt); $0.68 \%$ total nitrogen (wt), $0.064 \%$ phosphorus (wt), and $0.398 \%$ potassium (wt). Avocado trees were irrigated with microsprinklers during dry months and received $25 \mathrm{~cm}$ of rainfall in 1994-95 and $58 \mathrm{~cm}$ in 1995-96. No fungicides or other soil amendments were applied to these trees. Mulches were previously applied in a completely randomized design to the entire grove.

The Ashburner system of inducing suppression to Phytophthora spp. has two principal components: an organic matter source (which has been quite variable, everything from green manures to slash) and a lime source, as well as animal manures. In our modifications to the Ashburner system, we only applied eucalyptus chips, no green manures or cover crops and no animal manures.

Tree selection and sampling. Five pairs of trees (one mulched one unmulched in each pair) of similar size and condition and field location were randomly chosen as replicates. Using a trowel, samples ( 0.5 liter) of mulch and soil were collected from the following locations, forming a vertical transect: mulch surface, middle mulch, soil-mulch interface, soil to a $7.5 \mathrm{~cm}$ depth, and soil between 7.5 and $15 \mathrm{~cm}$ depths. Unmulched trees were sampled at 1 (soil surface), 7.5, and $15 \mathrm{~cm}$ depth. Two sets of samples were taken from each tree on the east and west points, inline with the sprinkler irrigation system, $1 \mathrm{~m}$ from the trunk. Samples were stored at $5^{\circ} \mathrm{C}$ until assayed. Assays were conducted within 2 weeks of sampling. All transect sample data were developed from the two samples per tree, which were averaged before further statistical analysis. Samples were taken in the winter of the third year after planting (January 1996) and again in early spring of that year (March 1996).

Saprophytic fungal populations. Soil fungal populations were surveyed from samples taken from each tree. Samples collected in
December 1995 from compass points of each tree were extracted from the surface to a $15 \mathrm{~cm}$ depth with a $2-\mathrm{cm}$-diameter soil core extractor. These samples were pooled, diluted $\left(10^{-5}\right)$, and plated onto two plates each of three different media: rose bengal medium (45), potato dextrose agar (Difco Laboratories, Detroit), and cellulose agar (37). All media were amended with ampicillin (100 ppm) and streptomycin sulfate $(100 \mathrm{ppm})$ to limit bacterial growth. Soil fungal sampling was repeated in December 1996. All fungi growing on plates were identified and enumerated. Because 1995 and 1996 data were not different, data from 1995 and 1996 were averaged before analysis. Periodically, soils and mulches from these trees also were observed visually for 2 years to detect fruiting bodies of basidiomycete fungi. Fungi sighted in visual surveys in February, March, and June were tabulated and converted to frequency of occurrence (percent) values.

Transect survey of fungal populations. Total fungal populations were estimated in vertical transect samples (described previously) by dilution plating methods (47). Samples suspended (10 g dry wt) in $90 \mathrm{ml}$ of sterile distilled water were diluted fivefold and plated onto rose bengal medium (45). Fungi were counted and identified to genus level. Two plates were used per sample, and the counts were averaged. The experiment was conducted two times.

Microbial activity. Microbial activity of mulch and soil from the vertical transect samples was determined by the hydrolysis of fluorescein diacetate (FDA) using the method described initially by Schnurer and Rosswall (40), with modifications introduced by Inbar et al. (23) and Boehm and Hoitink (4). Five grams of sample was added to $20 \mathrm{ml}$ of $60 \mathrm{mM}$ phosphate buffer $\left(\mathrm{Na}_{2} \mathrm{HPO}_{4}+\mathrm{Na}\right.$ $\mathrm{H}_{2} \mathrm{PO}_{4}$ ), $\mathrm{pH}$ 7.6. FDA (Sigma Chemical, St. Louis) was added to the samples $\left(0.2 \mathrm{ml}\right.$ of $2 \mathrm{mg} \mathrm{ml}^{-1}$ FDA stock solution) that were agitated on a rotary shaker at $150 \mathrm{rpm}$ for $1 \mathrm{~h}$. Acetone $(20 \mathrm{ml})$

TABLE 1. Populations of soil and mulch fungi from standard isolations and visual observations from mulched (M) and nonmulched (NM) plots

\begin{tabular}{|c|c|c|c|c|c|c|c|c|}
\hline \multirow[b]{3}{*}{ Fungal genus } & \multicolumn{6}{|c|}{ Soil dilution media ${ }^{y}$} & & \\
\hline & \multicolumn{2}{|c|}{ Rose bengal medium } & \multicolumn{2}{|c|}{ Potato dextrose agar } & \multicolumn{2}{|c|}{ Cellulose agar } & \multicolumn{2}{|c|}{ Visual observations $^{\mathrm{z}}$} \\
\hline & M & NM & M & NM & M & NM & M & NM \\
\hline \multicolumn{9}{|l|}{ Populations $\times 10^{5}$} \\
\hline Ceraceomyces & $\ldots$ & $\ldots$ & $\ldots$ & $\ldots$ & $\ldots$ & $\ldots$ & 83 & 0 \\
\hline Phanerochaete & $\ldots$ & $\ldots$ & $\ldots$ & $\ldots$ & $\ldots$ & $\ldots$ & 100 & 0 \\
\hline Physarum & $\ldots$ & $\ldots$ & $\ldots$ & $\ldots$ & $\ldots$ & $\ldots$ & 35 & 0 \\
\hline Conoplea & $\ldots$ & $\ldots$ & $\ldots$ & $\ldots$ & $\ldots$ & $\ldots$ & 17 & 0 \\
\hline \multicolumn{9}{|l|}{ Hyphomycetes } \\
\hline Penicillium & 3.5 & 0.9 & 3.1 & 0.77 & 2.2 & 1.5 & $\ldots$ & $\ldots$ \\
\hline Aspergillus & 2.3 & 0.5 & 2.0 & 0.8 & 2.0 & 0.14 & $\ldots$ & $\ldots$ \\
\hline Chalariopsis & 0.9 & 0.04 & 0.04 & 0 & 0 & 0 & $\ldots$ & $\ldots$ \\
\hline Sporothrix & 0.6 & 0.2 & 0.4 & 0 & 0.2 & 0.1 & $\ldots$ & $\ldots$ \\
\hline Phoma & 0.5 & 0.3 & 0 & 0.04 & 0 & 0 & $\ldots$ & $\ldots$ \\
\hline Trichoderma & 0.4 & 0.0 & 0.3 & 0 & 0.4 & 0.4 & 50 & 0 \\
\hline Saccharomyces & 0.3 & 0.9 & 0.17 & 0.04 & 0 & 0 & $\ldots$ & $\ldots$ \\
\hline Scopulariopsis & 0.3 & 0.5 & 0 & 0 & 0.05 & 0 & $\ldots$ & $\ldots$ \\
\hline Paecilomyces & 0.2 & 0.04 & 0 & 0 & 0 & 0 & $\ldots$ & $\ldots$ \\
\hline Aureobasidium & 0.17 & 0.04 & 0.5 & 0 & 0 & 0 & $\ldots$ & $\ldots$ \\
\hline Cladosporium & 0.14 & 0.2 & 0.18 & 0.21 & 0.2 & 0.14 & $\ldots$ & $\ldots$ \\
\hline Acremonium & 1.0 & 0.12 & 0.6 & 0.9 & 0.05 & 0 & $\ldots$ & $\ldots$ \\
\hline Septonema & 0.1 & 0.1 & 0.04 & 0.05 & 0.05 & 0 & $\ldots$ & $\ldots$ \\
\hline Verticillium & 0.1 & 0 & 0.05 & 0 & 0.05 & 0.4 & $\ldots$ & $\ldots$ \\
\hline Fusarium & 0.1 & 0 & 0 & 0 & 0 & 0 & $\ldots$ & $\ldots$ \\
\hline Gliocladium & 0.1 & 0 & 0 & 0 & 0 & 0 & $\ldots$ & $\ldots$ \\
\hline Ulocladium & 0.05 & 0 & 0 & 0.05 & 0 & 0 & $\ldots$ & $\ldots$ \\
\hline Pythium & 0.04 & 0 & 0 & 0.13 & 0 & 0 & $\ldots$ & $\ldots$ \\
\hline Torula & 0 & 0 & 0 & 0 & 0 & 0.05 & $\ldots$ & $\ldots$ \\
\hline Humicola & 0 & 0 & 0 & 0.05 & 0 & 0 & $\ldots$ & $\ldots$ \\
\hline Cylindrocladium & 0 & 0 & 0 & 0 & 0 & 0.05 & $\ldots$ & $\ldots$ \\
\hline Unknown & 0.19 & 0.5 & 0.05 & 0.1 & 0.94 & 0.5 & $\ldots$ & $\ldots$ \\
\hline Total number of genera & 19 & 13 & 12 & 11 & 11 & 8 & $\ldots$ & $\ldots$ \\
\hline
\end{tabular}

y Numbers are means of five samples from M and NM trees.

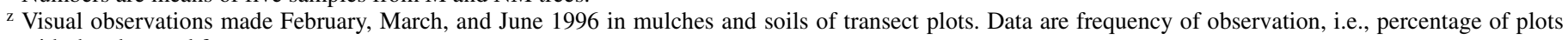
with the observed fungus. 
was added to stop the reaction. Aliquots of $1.5 \mathrm{ml}$ were taken from each sample and centrifuged in a microfuge at 13,000 rpm for 2 min. Absorbance was measured at $490 \mathrm{~nm}$ with a spectrophotometer (LKB Biochrom Ultraspec K; Phoenix Equipment Inc., Rochester, NY). Standard curves for fluorescein hydrolysis were prepared for each mulch or soil sample to avoid errors caused by adsorption of fluorescein to organic matter. A range of fluorescein concetrations $(0,100,200,300$, and $400 \mu \mathrm{g})$ was added to $5 \mathrm{ml}$ of buffer and completely hydrolyzed in a boiling water bath for $60 \mathrm{~min}$. The fluorescein and $15 \mathrm{ml}$ of additional buffer were added to soil or mulch samples as described previously, incubated, shaken, and acetone was added and analyzed as described previously. Two determinations were made on each transect sample. There were five replications of each mulched and unmulched transect sample, and the experiment was conducted twice.

Enzyme activities. Soil and mulch enzymes were extracted and assayed as described in Alef and Nannipieri (2) with the following modifications. Ten grams (dry wt) of each sample was measured in a $125-\mathrm{ml}$ Erlenmeyer flask. To each flask, $15 \mathrm{ml}$ of $0.05 \mathrm{M}$ acetate buffer was added. The appropriate substrate was suspended in acetate buffer and $15 \mathrm{ml}$ was added to the reaction (soil or mulch) mixture. Substrates were carboxymethyl cellulose $(0.7 \%$, $\mathrm{wt} / \mathrm{vol}$, medium viscosity) (Sigma Chemical), laminarin $(0.1 \%$, wt/vol) (Sigma Chemical), and Phytophthora cinnamomi cell walls $(0.1 \%, \mathrm{wt} / \mathrm{vol})$ for the detection of total cellulase activity, $\beta$ 1,3-glucanase, and Phytophthora-degrading enzymes (Phytophthora 'ase'), respectively. Flasks were agitated constantly on a rotary shaker at $100 \mathrm{rpm}$ for $4 \mathrm{~h}$ at $36^{\circ} \mathrm{C}$. Controls were prepared by adding $15 \mathrm{ml}$ of substrate-buffer solution after incubation of reaction mixtures without substrate but immediately before centrifugation. Aliquots of $1.5 \mathrm{ml}$ were removed in microcentrifuge tubes and spun at 13,000 rpm for $3 \mathrm{~min}$. The supernatant was assayed for reducing sugars according to the methods of Schinner and Von Mersi (39), with modifications made to analyze the smaller volumes. Optical density was measured at $690 \mathrm{~nm}$ for color development. Treatments were analyzed after subtracting the zero time substrate-added sample values to correct for background levels of reducing sugars associated with organic matter. Assays were run in duplicate and averaged before further statistical analysis. There were five replications of each mulched and unmulched transect sample, and the experiment was conducted twice.
To obtain cell walls of Phytophthora cinnamomi, liquid cultures of isolate M-295 obtained from the field of study were grown in $500 \mathrm{ml}$ of half-strength $\mathrm{V} 8-\mathrm{C}(708 \mathrm{ml}$ of $\mathrm{V} 8$ juice and $10 \mathrm{~g}$ of $\mathrm{CaCO}_{3}$ were centrifuged at $9,000 \mathrm{rpm}$ for $20 \mathrm{~min}$ to clarify the mixture; $200 \mathrm{ml}$ of the supernatant was mixed with $15 \mathrm{~g}$ of agar plus $800 \mathrm{ml}$ of deionized water) broth in 1-liter Erlenmeyer flasks for 2 weeks in the dark at $24^{\circ} \mathrm{C}$ in stationary culture (34). Flask cultures were initiated with agar disks (3-mm diameter) cut from the margin of a colony of Phytophthora cinnamomi. Mycelia were harvested and chopped in an omnimixer (Sorvall; OCI Instruments, Waterbury, CT) for $1 \mathrm{~min}$ and centrifuged at 3,000 rpm for $20 \mathrm{~min}$. The pellet was resuspended in deionized water, and the process was repeated three times to remove the broth. Hyphae were further broken with glass beads according to the method by Lippman et al. (30). The resulting preparation was rinsed, centrifuged as previously described, lyophilized, and stored at $-20^{\circ} \mathrm{C}$. This crude preparation contained cell walls free of cytoplasm (verified microscopically) and was used as substrate for enzyme assays.

Phytophthora inoculum potential. Phytophthora cinnamomi and total Phytophthora spp. (Phytophthora cinnamomi plus Phytophthora citricola) inoculum potentials were estimated from vertical transect samples with a leaf disk-baiting assay. The assay consisted of a $1-\mathrm{g}$ soil or mulch sample suspended in $9 \mathrm{ml}$ of distilled water placed in a standard petri plate $(15 \times 100 \mathrm{~mm})$. In each plate, 10 leaf disks (3-mm diameter) of Persea indica (L.) Spreng (an avocado relative very susceptible to Phytophthora cinnamomi) were floated for 3 days. The disks were removed and placed on PARPH medium (27). Plates were incubated at $24^{\circ} \mathrm{C}$ in the dark and examined after 3 days. Colonies of Phytophthora cinnamomi and Phytophthora citricola were identified when hyphae grew in the agar medium. Data were recorded as the number out of 10 disks infected with Phytophthora. The same number of replications and repetitions was used as described previously for other transect samples.

Phytophthora fecundity, lysis, and hyperparasitism. Phytophthora cinnamomi M-295 was cultured on V8-C medium in the dark at $24^{\circ} \mathrm{C}$. All experiments described here were conducted with isolate M-295. Five-millimeter disks from an actively growing culture of Phytophthora cinnamomi were transferred to petri plates $(15 \times 60 \mathrm{~mm})$ covered with $7 \mathrm{ml}$ of half-strength V8-C broth and placed in the dark for 3 days. Resultant mycelia were

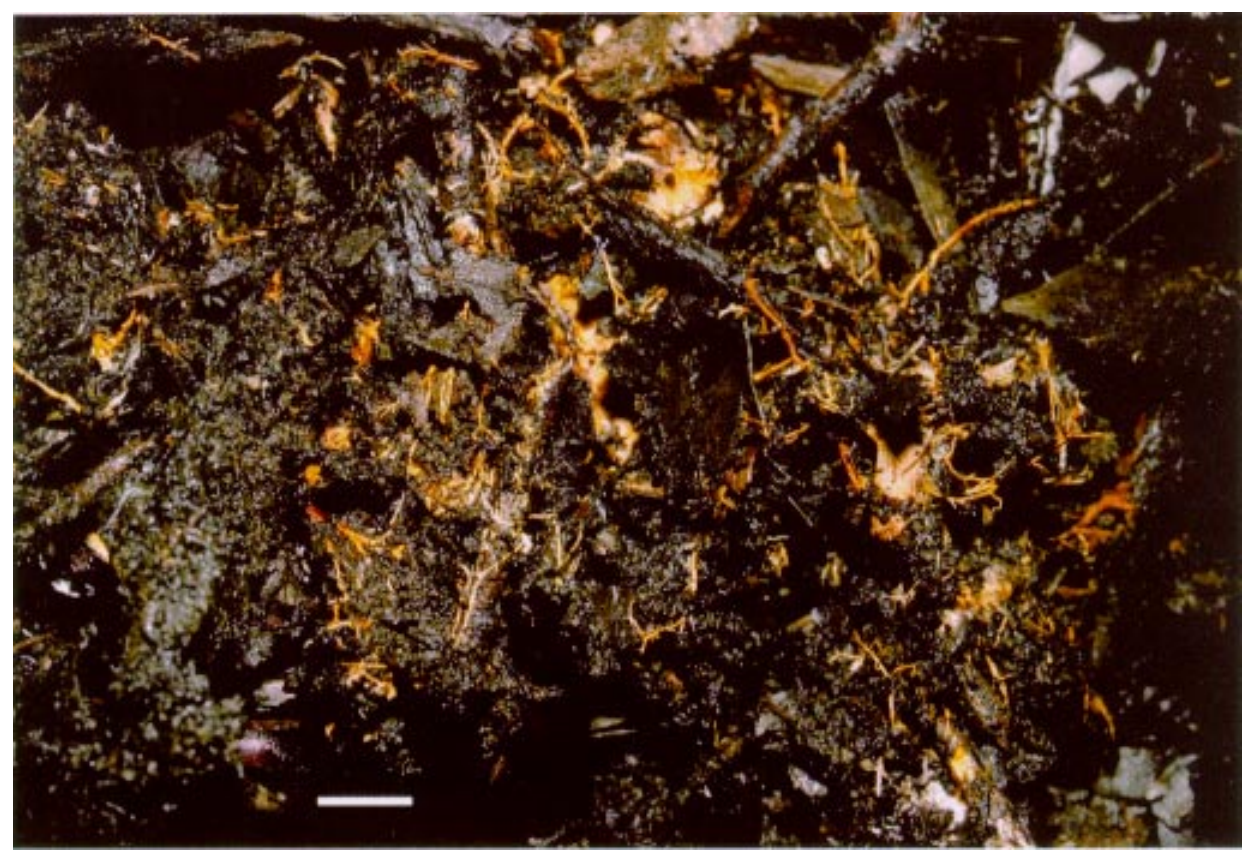

Fig. 1. Cordons of Phanerochaete chrysorhiza throughout the mulch. 
washed three times with deionized water, and mycelial mats were placed in 100- $\mu \mathrm{m}$ mesh Miracloth (Behring Diagnostics, La Jolla, $\mathrm{CA}$ ) envelopes that were secured in $35-\mathrm{mm}$ plastic slide mounts. After placement in the field but prior to microscopic examination for lysis and hyperparasitism, mycelia were washed with deionized water, moved to petri plates $(15 \times 60 \mathrm{~mm})$, and incubated at $4{ }^{\circ} \mathrm{C}$ for $0.5 \mathrm{~h}$. For determination of zoospore production, mycelia were incubated at $25^{\circ} \mathrm{C}$ (room temperature) for $30 \mathrm{~min}$ to induce zoospore release. Phytophthora cinnamomi fecundity was estimated by counting zoospores with a counting chamber (Hawksley \& Sons Ltd., Lancing West Suffex, England).

Mycelial mats were buried at the various vertical transect depths mentioned previously and were recovered from the field after 3 days. The mycelia were washed with deionized water and portions of the mycelium were examined at $\times 100$ magnification for lysis and hyperparasitism. Lysis was rated on a scale of 1 to 5: $1=$ no lysis, healthy mycelium; $2=$ most mycelium healthy with some vacuolated hyphae present; $3=$ extensive vacuolation, hyphae disintegrating; 4 = hyphal fragments abundant, protoplasm only in hyphal tips; and $5=$ mycelium dissolved with only hyphal fragments remaining.

Roots and root infections. Roots were removed from all vertical transect samples, as described previously, before analysis and retained for root length calculations and isolation of Phytophthora cinnamomi. Root length was calculated with the line intersection method (36). Data were expressed as root length (centimeter) per gram of sampled soil or mulch. After root length determinations were made, $1-\mathrm{cm}$ root pieces (10 per sample) were placed on PARPH medium and incubated in the dark at $24^{\circ} \mathrm{C}$ for 3 days. Phytophthora cinnamomi was identified when its characteristic hyphae grew in the medium.

\section{RESULTS}

Saprophytic fungal populations. Although significantly higher populations of hyphomycete fungi were isolated on rose bengal medium from mulched soils than from unmulched soils (significant at $P<0.05, t$ value in a paired $t$ test) (Table 1 ), significant differences between mulched and unmulched samples were not observed on the other media. Some genera occurred in significantly greater number in mulched soils than unmulched soils (data not shown). Penicillium and Aspergillus were the most frequently isolated hyphomycetes from both mulched and unmulched soils; however, they occurred significantly (significant paired $t$ value at $P<0.01)$ more in mulched soil samples. Trichoderma spp. were observed in $50 \%$ of mulched plots but were not observed in unmulched plots. All mulches contained mycelial strands of a basidiomycete, Phanerochaete chrysorhiza (Torr.) Budington \& R.L. Gilbertson, and over $80 \%$ of mulched plots contained Ceraceomyces tessulatus (Cooke) Jülich (Table 1). These white-rot wood decay fungi were abundant, totally distributed throughout the mulch (Fig. 1), but were absent in unmulched soils. These fungi could not be enumerated with any of the standard isolation techniques on agar.

Transect survey of fungal populations. Samples from mulches had more fungi in more genera than soil samples from unmulched trees. Samples from mulched trees yielded $87 \%$ of the total fungal colonies isolated, comprising 31 fungal genera, whereas unmulched soils yielded $23 \%$ with 21 genera (Table 2). Mulch layers had significantly greater numbers of fungal propagules than soil from mulched or unmulched trees (Table 3). The interface samples from mulched trees contained significantly more fungi than surface samples from unmulched trees.

TABLE 2. Fungal populations isolated on rose bengal medium from transect samples collected from mulched and unmulched avocado trees ${ }^{\mathrm{z}}$

\begin{tabular}{|c|c|c|c|c|c|c|c|c|c|c|}
\hline \multirow[b]{2}{*}{ Fungus } & \multicolumn{10}{|c|}{ Population/g $\times 10^{5}$} \\
\hline & $\mathrm{Sm}$ & $\mathrm{Mm}$ & I & $\mathrm{Sm} 1$ & $\mathrm{Sm} 2$ & Tot & Ss & $\mathrm{S} 1$ & $\mathrm{~S} 2$ & Tot \\
\hline Aspergillus & 6.3 & 10.1 & 8.9 & 6.3 & 2.2 & 33.8 & 0.7 & 1.2 & 1.4 & 3.3 \\
\hline Penicillium & 7.5 & 11.0 & 8.9 & 2.8 & 1.3 & 31.5 & 0.8 & 0.7 & 1.1 & 2.6 \\
\hline Sporothrix & 2.2 & 5.8 & 2.0 & 5.5 & 0.4 & 15.9 & 0.4 & 0.4 & 0.4 & 1.2 \\
\hline Phoma & 8.4 & 2.3 & 1.9 & 0.9 & 1.0 & 14.5 & 0.5 & 0.2 & 0.1 & 0.8 \\
\hline Saccharomyces & 10.9 & 2.5 & 0.6 & 0.3 & 0.2 & 14.5 & 0.05 & 0.0 & 0.1 & 0.2 \\
\hline Trichoderma & 1.0 & 2.5 & 1.2 & 0.8 & 0.7 & 6.2 & 0.1 & 0.2 & 0.1 & 0.4 \\
\hline Streptothrix & 1.9 & 0.8 & 1.1 & 0.2 & 0.3 & 4.3 & 0.0 & 0.0 & 0.0 & 0.0 \\
\hline Chalariopsis & 1.2 & 1.0 & 0.6 & 0.2 & 0.3 & 3.3 & 0.6 & 0.2 & 0.4 & 1.2 \\
\hline Cladosporium & 2.1 & 0.5 & 0.5 & 0.0 & 0.1 & 3.2 & 0.7 & 0.1 & 0.1 & 0.9 \\
\hline Scopulariopsis & 1.8 & 0.7 & 0.2 & 0.2 & 0.05 & 3.0 & 0.0 & 0.0 & 0.05 & 0.05 \\
\hline Acremonium & 1.5 & 0.7 & 0.3 & 0.3 & 0.0 & 2.8 & 0.2 & 0.0 & 0.05 & 0.3 \\
\hline Fusarium & 1.4 & 0.3 & 0.2 & 0.05 & 0.0 & 2.1 & 0.2 & 0.7 & 0.1 & 1.0 \\
\hline Septonema & 0.9 & 0.6 & 0.4 & 0.0 & 0.0 & 1.9 & 0.01 & 0.0 & 0.2 & 0.2 \\
\hline Phialophora & 1.0 & 0.3 & 0.0 & 0.2 & 0.0 & 1.5 & .03 & 0.0 & 0.0 & 0.3 \\
\hline Scolecobasidium & 0.3 & 1.0 & 0.2 & 0.0 & 0.0 & 1.5 & 0.0 & 0.0 & 0.0 & 0.0 \\
\hline Torula & 0.8 & 0.3 & 0.05 & 0.05 & 0.0 & 1.1 & 0.05 & 0.0 & 0.2 & 0.07 \\
\hline Aureobasidium & 0.6 & 0.1 & 0.05 & 0.1 & 0.0 & 0.9 & 0.0 & 0.2 & 0.0 & 0.2 \\
\hline Gliocladium & 0.0 & 0.1 & 0.2 & 0.3 & 0.2 & 0.8 & 0.1 & 0.3 & 0.0 & 0.4 \\
\hline Alternaria & 0.5 & 0.1 & 0.05 & 0.0 & 0.0 & 0.7 & 0.01 & 0.0 & 0.03 & 0.04 \\
\hline Hansfordia & 0.0 & 0.5 & 0.2 & 0.0 & 0.0 & 0.7 & 0.0 & 0.0 & 0.0 & 0.0 \\
\hline Verticillium & 0.05 & 0.05 & 0.1 & 0.2 & 0.2 & 0.6 & 0.1 & 0.0 & 0.1 & 0.2 \\
\hline Amblyosporium & 0.1 & 0.0 & 0.05 & 0.0 & 0.4 & 0.6 & 0.0 & 0.0 & 0.0 & 0.0 \\
\hline Cylindrocarpon & 0.2 & 0.0 & 0.05 & 0.0 & 0.2 & 0.5 & 0.05 & 0.05 & 0.1 & 0.2 \\
\hline Hyalodendron & 0.4 & 0.0 & 0.0 & 0.0 & 0.0 & 0.4 & 0.0 & 0.0 & 0.0 & 0.0 \\
\hline Stemphylium & 0.3 & 0.0 & 0.0 & 0.0 & 0.0 & 0.3 & 0.0 & 0.0 & 0.0 & 0.0 \\
\hline Phycomyces & 0.2 & 0.05 & 0.05 & 0.0 & 0.0 & 0.3 & 0.0 & 0.0 & 0.0 & 0.0 \\
\hline Pythium & 0.0 & 0.0 & 0.1 & 0.05 & 0.0 & 0.2 & 0.2 & 0.05 & 0.01 & 0.2 \\
\hline Ulocladium & 0.2 & 0.05 & 0.05 & 0.0 & 0.0 & 0.2 & 0.0 & 0.0 & 0.1 & 0.1 \\
\hline Mucor & 0.05 & 0.05 & 0.05 & 0.0 & 0.0 & 0.2 & 0.0 & 0.0 & 0.0 & 0.0 \\
\hline Oidiodendron & 0.05 & 0.0 & 0.0 & 0.0 & 0.0 & 0.1 & 0.0 & 0.0 & 0.0 & 0.0 \\
\hline Epicoccum & 0.05 & 0.0 & 0.0 & 0.0 & 0.0 & 0.1 & 0.0 & 0.0 & 0.0 & 0.0 \\
\hline Paecilomyces & 0.0 & 0.0 & 0.05 & 0.0 & 0.0 & 0.1 & 0.1 & 0.1 & 0.0 & 0.2 \\
\hline Total number of genera & 28 & 24 & 27 & 17 & 14 & 32 & 18 & 13 & 18 & 22 \\
\hline
\end{tabular}

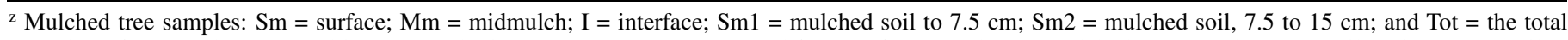
number of genera that occurred in the sample, i.e., 28 genera were recovered from surface samples. Unmulched tree samples: Ss $=$ soil surface; S1 = soil to $7.5 \mathrm{~cm}$; and S2 = soil, 7.5 to $15 \mathrm{~cm}$. Data are averages for five replicate samples from each of two dates in January and March 1996. 
Microbial activity. Microbial activity, expressed as the microgram of fluorescein hydrolyzed per gram of sample per hour, was significantly greater in surface and midmulch profiles and dropped off rapidly in underlying soils. Microbial activity was significantly greater $(P<0.001)$ at the mulch-soil interface than the unmulched soil surface. There were no differences in microbial activity between mulched and unmulched soils at 7.5 and $15 \mathrm{~cm}$ depths. Microbial activity was numerically, very low in unmulched soil and did not vary with depth (Table 4).

Enzyme activities. Cellulase (cellulase complex), laminarinase, and enzymes active against Phytophthora cinnamomi cell walls were most abundant in the surface and midmulch layers of organic matter under mulched trees (Table 4). Cellulase activity was significantly greater in the interface of mulched trees than at the surface of unmulched trees in one of the two experiments (Table 4). Enzyme activities in the deepest samples were similar and low. There were no differences in enzyme activities between mulched and unmulched soils.

Phytophthora inoculum potential. Phytophthora populations consisting of Phytophthora citricola and Phytophthora cinnamomi were not recovered from any upper mulch layers (Table 3). Although Phytophthora was recovered from interface samples, there were significantly fewer recoveries than from underlying soil layers. Total Phytophthora recovery was positively correlated with sample depth $\left(r^{2}=0.731: y=2.954+0.301 x, P<0.001\right)$; the highest inoculum potential was in the lower soil profiles of mulched and unmulched trees. Phytophthora cinnamomi recovery was similar in the 7.5 and $15 \mathrm{~cm}$ depths of mulched and unmulched soils.
Phytophthora fecundity, lysis, and hyperparasitism. Zoospore production was lowest in surface mulch and soil surface (of nonmulched trees) samples. Mycelia incubated in soil profiles, especially those under mulch, produced significantly more zoospores than surface-incubated mycelia (Table 5). In mulched trees, significantly fewer spores were produced from mycelia incubated at the interface compared with mycelia incubated in soil $(7.5 \mathrm{~cm})$.

Lysis of Phytophthora cinnamomi hyphae was significantly greater in mulched than in unmulched soils and was numerically greatest at the interface of soil and mulch (significant orthogonal contrasts, $P, 0.001$, treatments 4 and 5 versus 7 and 8) (Table 5). Lysis at the interface of mulch and soil was significantly greater than any lysis rated for samples incubated in unmulched soils; in some cases, the mycelium was completely disrupted (Fig. 2B). There were no statistical differences in hyperparasitism at any of the soil and mulch depths (data not shown).

Roots and root infections. Avocado roots were not found in surface mulch samples, but were recovered from midmulch and interface mulch layers where Phytophthora recoveries were reduced. Mulched trees had significantly more roots in the interface zone than unmulched trees had near the soil surface (Table 6). Root lengths in unmulched soil were greatest at $7.5 \mathrm{~cm}$ depth where high populations of Phytophthora (Table 3) were also found. Mulched trees had similar amounts of roots at 7.5 and $15 \mathrm{~cm}$ depths. Significantly more avocado roots were measured under mulched soils than unmulched soils (significant orthogonal contrasts, treatments 3 to 5 versus 6 to $8, P<0.05$, for both sampling dates). Avocadoes partition their roots in two strata

TABLE 3. Fungal populations associated with mulches and unmulched soils

\begin{tabular}{|c|c|c|c|c|c|c|}
\hline \multirow[b]{2}{*}{ Treatment } & \multicolumn{2}{|c|}{ Total fungal CFU } & \multicolumn{2}{|c|}{ Total Phytophthora ${ }^{\mathrm{y}}$} & \multicolumn{2}{|c|}{ Phytophthora cinnamomi } \\
\hline & $\mathrm{I}^{\mathrm{z}}$ & II & I & II & I & II \\
\hline \multicolumn{7}{|l|}{ Mulched trees } \\
\hline 1. Mulch surface & $35.0 \mathrm{ab}$ & $93.2 \mathrm{a}$ & $0.0 \mathrm{~b}$ & $0.0 \mathrm{c}$ & $0.0 \mathrm{~b}$ & $0.0 \mathrm{~b}$ \\
\hline 2. Midmulch & $45.0 \mathrm{a}$ & $58.5 \mathrm{~b}$ & $0.0 \mathrm{~b}$ & $0.0 \mathrm{c}$ & $0.0 \mathrm{~b}$ & $0.0 \mathrm{~b}$ \\
\hline 3. Interface & $26.6 \mathrm{bc}$ & $43.3 \mathrm{bc}$ & $1.2 \mathrm{~b}$ & $1.8 \mathrm{c}$ & $0.0 \mathrm{~b}$ & $0.2 \mathrm{ab}$ \\
\hline 4. Soil $7.5 \mathrm{~cm}$ & $10.1 \mathrm{~cd}$ & $31.8 \mathrm{~cd}$ & $4.8 \mathrm{a}$ & $6.0 \mathrm{~b}$ & $1.2 \mathrm{a}$ & $0.0 \mathrm{ab}$ \\
\hline 5. Soil $15 \mathrm{~cm}$ & $6.4 \mathrm{~d}$ & $17.5 \mathrm{de}$ & $5.8 \mathrm{a}$ & $8.3 \mathrm{ab}$ & $0.6 \mathrm{ab}$ & $0.3 \mathrm{a}$ \\
\hline \multicolumn{7}{|l|}{ Unmulched trees } \\
\hline 6. Surface & $4.1 \mathrm{~d}$ & $11.3 \mathrm{e}$ & $0.0 \mathrm{~b}$ & $1.67 \mathrm{c}$ & $0.0 \mathrm{~b}$ & $0.0 \mathrm{~b}$ \\
\hline 7. Soil $7.5 \mathrm{~cm}$ & $2.9 \mathrm{~d}$ & $14.0 \mathrm{de}$ & $7.8 \mathrm{a}$ & $8.17 \mathrm{ab}$ & $1.0 \mathrm{a}$ & $0.0 \mathrm{~b}$ \\
\hline 8. Soil $15 \mathrm{~cm}$ & $3.4 \mathrm{~d}$ & $13.2 \mathrm{e}$ & $5.2 \mathrm{a}$ & $10.0 \mathrm{a}$ & $0.4 \mathrm{ab}$ & $0.2 \mathrm{ab}$ \\
\hline
\end{tabular}

$\mathrm{x}$ Total fungal CFU are fungal colonies $\left(\times 10^{5}\right)$ per gram of soil, counted on rose bengal medium.

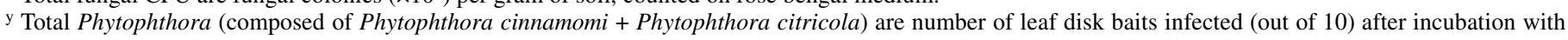
$1 \mathrm{~g}$ of sample. Baits were plated on PARPH medium. Means followed by the same letter were not significantly different according to two-way analysis of variance and LSD $(P<0.05)$ using five replications of mulched and unmulched tree pairs.

z I and II refer to samples one and two, respectively. Samples were collected on January 1996 for I and March 1996 for II.

TABLE 4. Microbial and enzyme activities associated with mulches and unmulched soils

\begin{tabular}{|c|c|c|c|c|c|c|c|c|}
\hline \multirow[b]{3}{*}{ Treatment } & \multirow{2}{*}{\multicolumn{2}{|c|}{$\frac{\text { Microbial activity }^{\mathrm{x}}}{\text { Fluorescein diacetate }}$}} & \multicolumn{6}{|c|}{ Enzyme activities $^{\mathrm{y}}$} \\
\hline & & & \multicolumn{2}{|c|}{ Carboxymethyl cellulose } & \multicolumn{2}{|c|}{ Laminarinase } & \multicolumn{2}{|c|}{ P.cinnase } \\
\hline & $\mathrm{I}^{\mathrm{Z}}$ & II & I & II & I & II & I & II \\
\hline \multicolumn{9}{|l|}{ Mulched trees } \\
\hline 1. Mulch surface & $1.17 \mathrm{a}$ & $1.37 \mathrm{a}$ & $4.29 \mathrm{a}$ & $4.22 \mathrm{a}$ & $45.58 \mathrm{a}$ & $11.83 \mathrm{a}$ & $5.33 \mathrm{a}$ & $2.63 \mathrm{a}$ \\
\hline 2. Midmulch & $1.30 \mathrm{a}$ & $1.58 \mathrm{a}$ & $3.41 \mathrm{ab}$ & $3.28 \mathrm{a}$ & $8.45 \mathrm{~b}$ & $9.63 \mathrm{a}$ & $3.60 \mathrm{ab}$ & $1.53 \mathrm{a}$ \\
\hline 3. Interface & $0.63 \mathrm{a}$ & $1.49 \mathrm{~b}$ & $1.57 \mathrm{bc}$ & $1.44 \mathrm{~b}$ & $3.36 \mathrm{~b}$ & $3.33 \mathrm{~b}$ & $0.91 \mathrm{bc}$ & $0.38 \mathrm{~b}$ \\
\hline 4. Soil $7.5 \mathrm{~cm}$ & $0.04 \mathrm{~b}$ & $0.63 \mathrm{c}$ & $0.14 \mathrm{c}$ & $0.30 \mathrm{c}$ & $2.03 \mathrm{~b}$ & $0.12 \mathrm{~b}$ & $0.13 \mathrm{bc}$ & $0.13 \mathrm{~b}$ \\
\hline 5. Soil $15 \mathrm{~cm}$ & $0.00 \mathrm{~b}$ & $0.28 \mathrm{c}$ & $0.11 \mathrm{c}$ & $0.15 \mathrm{c}$ & $2.78 \mathrm{~b}$ & $0.00 \mathrm{~b}$ & $0.27 \mathrm{bc}$ & $0.00 \mathrm{~b}$ \\
\hline \multicolumn{9}{|l|}{ Unmulched trees } \\
\hline 6. Surface & $0.01 \mathrm{~b}$ & $0.10 \mathrm{c}$ & $0.29 \mathrm{c}$ & $0.02 \mathrm{c}$ & $0.02 \mathrm{~b}$ & $0.04 \mathrm{~b}$ & $0.00 \mathrm{c}$ & $0.00 \mathrm{~b}$ \\
\hline 7. Soil $7.5 \mathrm{~cm}$ & $0.00 \mathrm{~b}$ & $0.05 \mathrm{c}$ & $0.49 \mathrm{c}$ & $0.02 \mathrm{c}$ & $1.67 \mathrm{~b}$ & $0.00 \mathrm{~b}$ & $0.00 \mathrm{c}$ & $0.13 \mathrm{~b}$ \\
\hline 8. Soil $15 \mathrm{~cm}$ & $0.00 \mathrm{~b}$ & $0.04 \mathrm{c}$ & $0.00 \mathrm{c}$ & $0.00 \mathrm{c}$ & $0.18 \mathrm{~b}$ & $0.08 \mathrm{~b}$ & $0.00 \mathrm{c}$ & $0.00 \mathrm{~b}$ \\
\hline
\end{tabular}

${ }^{x}$ Microbial activities are expressed as micrograms of fluorescein hydrolyzed per gram of sample per hour.

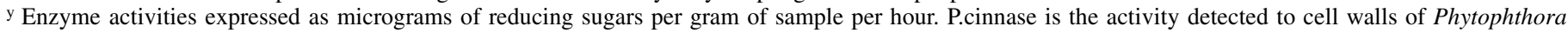
cinnamomi. Values are means of samples from five tree pairs. Column means followed by the same letter are not significantly different according to LSD $(P<0.05)$.

${ }^{\mathrm{z}}$ I and II refer to samples one and two, respectively. Samples were collected on January 1996 for I and March 1996 for II. 
when mulch is present: in the interface and at $7.5 \mathrm{~cm}$ depth. Roots observed growing in the mulch and interface zones appeared larger, white, and less branched, whereas roots growing in soil (mulched or unmulched trees) were dark, often rotted, and more branched. Phytophthora cinnamomi could not be isolated from roots growing in mulch (Table 6); yet, it was frequently isolated from roots at 7.5 and $15 \mathrm{~cm}$ depths.

Regressions. Microbial activity, cellulase, laminarinase, and Phytophthora cinnamomi 'ase' (P.cinase) production were all positively correlated with each other and all negatively correlated

TABLE 5. Fecundity, lysis, and hyperparasitism of Phytophthora cinnamomi mycelium placed in mulch and soil profiles

\begin{tabular}{lcl}
\hline Treatment & Zoospores per mg & Lysis rating $^{\mathrm{z}}$ \\
\hline Mulched trees & & \\
1. Surface & $603 \mathrm{c}$ & $1.4 \mathrm{bc}$ \\
2. Midmulch & $3,090 \mathrm{ab}$ & $2.8 \mathrm{a}-\mathrm{c}$ \\
3. Interface & $2,065 \mathrm{~b}$ & $4.5 \mathrm{a}$ \\
4. Soil $7.5 \mathrm{~cm}$ & $11,426 \mathrm{a}$ & $3.6 \mathrm{ab}$ \\
5. Soil $15 \mathrm{~cm}$ & $6,493 \mathrm{ab}$ & $3.1 \mathrm{a}-\mathrm{c}$ \\
Unmulched trees & & \\
$6.1 \mathrm{~cm}$ & $121 \mathrm{c}$ & $0.8 \mathrm{c}$ \\
$7.7 .5 \mathrm{~cm}$ & $3,640 \mathrm{ab}$ & $0.9 \mathrm{bc}$ \\
$8.15 \mathrm{~cm}$ & $2,269 \mathrm{~b}$ & $1.0 \mathrm{bc}$ \\
\hline
\end{tabular}

y Zoospores released per milligram of mycelium of Phytophthora cinnamomi recovered from each transect level after 3 days. Means followed by the same letter are not significantly different according to LSD $(P<0.05)$.

${ }^{z}$ Visual rating of the integrity of recovered mycelia of Phytophthora cinnamomi: $0=$ no lysis, healthy mycelium; and $5=$ mycelium completely dissolved.

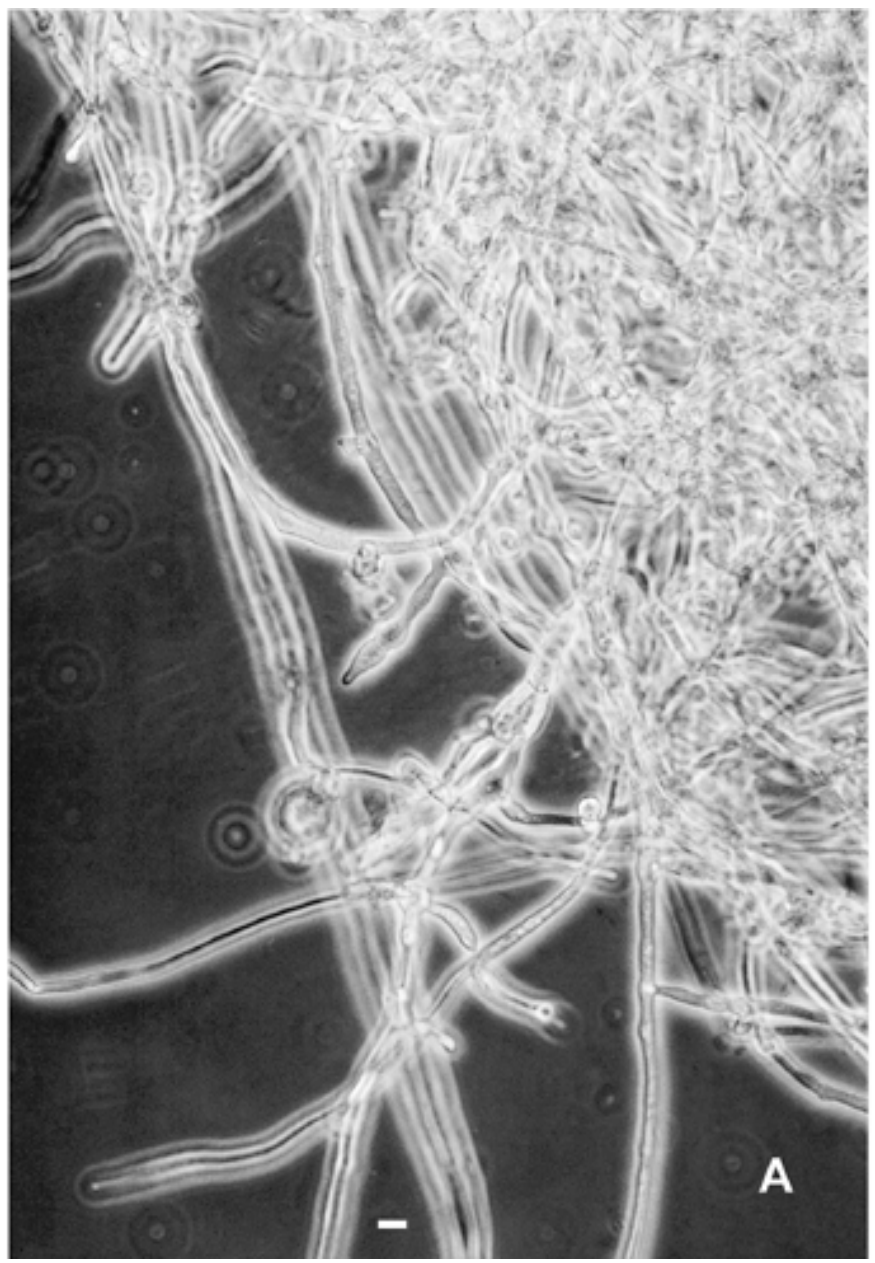

with Phytophthora inoculum potential. P.cinase was most correlated with carboxymethyl cellulase. Microbial activity in mulched soils was highly correlated with carboxymethyl cellulase activity $(P<0.001 ; r=0.770)$ (Table 7). Saprophytic fungal populations also correlated with increased enzyme activities and with microbial activity. Root lengths did not correlate positively with the various microbial activity parameters because of the absence of roots on the mulch surface (where enzyme activities were high) and the presence of roots in soil where enzyme activities were low (regression data not shown).

\section{DISCUSSION}

The Ashburner system of biological control was developed to simulate rain forest conditions in an avocado grove where all natural vegetation had been removed. It has reduced Phytophthora root rot in Australia and the United States (5,33). Despite much study in Australia, the mechanism of control has not been completely elucidated (24). Without forest trees, litterfall (a natural occurrence in forests) is simulated with mulch applications. Although litter layers support many kinds of organisms, they primarily promote the growth of fungi. The resulting mulch environment is suppressive to Phytophthora. As in the Ashburner model, we found that the prevalence of Phytophthora spp. Increases with distance from the mulch. Saprophytic fungal populations, microbial activity, cellulase activity, laminarinase activity, and avocado rooting all declined as distance from the mulch increased. We propose that the production of cellulase and laminarinase by litter decay fungi in mulch is a mechanism by which the Ashburner system reduces Phytophthora root rot of avocado.

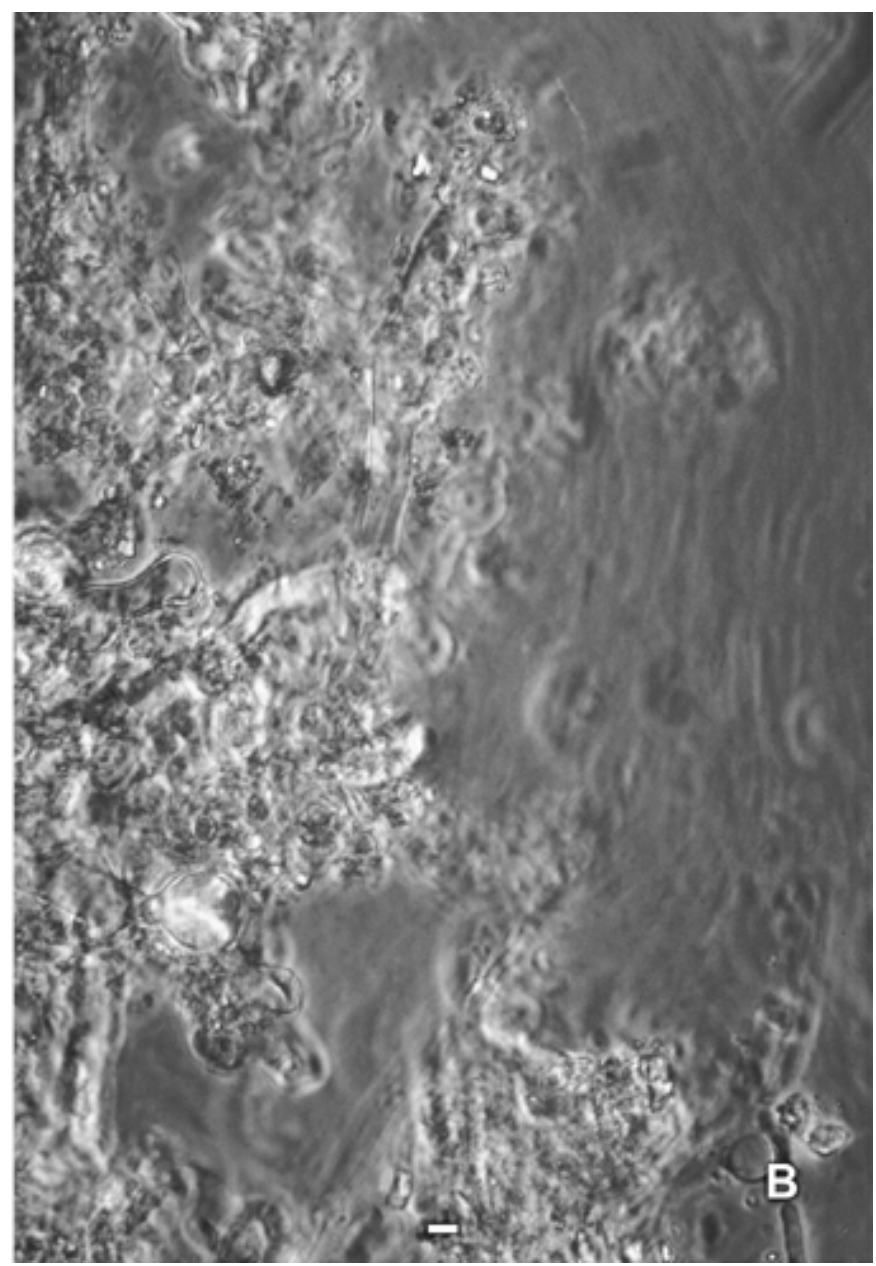

Fig. 2. Hyphae of Phytophthora cinnamomi recovered from $\mathbf{A}$, the soil of an unmulched tree, and $\mathbf{B}$, the interface of mulch and soil. 
In an attempt to implement the Ashburner mulching system in California soils, eucalyptus trimmings were used because of their abundance in California farms and landscapes. Coarse eucalyptus clippings with roughly chopped leaves and stems have a relatively high $\mathrm{C}: \mathrm{N}$ ratio $(\approx 100)$ and are a rich source of cellulose. Eucalyptus trimmings can make good mulch beneficial to the growth and establishment of trees $(15,16)$. Mulches added to plots around each tree in this study were the primary source of organic matter because the avocado trees were too young to produce enough litter of their own and to make significant organic matter contributions to the soil. In this study, organic matter in mulched plots was significantly associated with microbial activity, which was well correlated with cellulase and laminarinase production. Soil enzyme activities are usually limited by available substrate (44); thus, repeated additions of organic materials to soil increases many soil enzyme activities $(32,42,44)$. Our results are consistent with several other studies that indicated microbial activity was closely associated with organic layers in forest soil profiles $(6,26,29,48)$.

Organic matter serves two possible purposes that are important to biological control of Phytophthora cinnamomi: it provides substrate for growth of fungal antagonists and creates an environment that promotes enzyme activities. The importance of organic matter to enzyme activities and protection of enzymes from microbial degradation has been well established $(9,14,19,43)$. Thus, mulch serves as a reservoir of enzyme activity. Litter decomposition is a community-level process, requiring cellulase complexes and organisms with lignin-degrading ability in which complete systems of exo, endo, and disaccharide clipping hydrolases are present (42). A community of organisms producing mixtures of enzyme activities may explain the general suppression often attributed to the Ashburner system. Broadbent and Baker (5) related control of Phytophthora cinnamomi in organic mulches to the lytic action of bacteria that were associated with degrading hyphae of Phytophthora cinnamomi. However, bacteria will accumulate near any damaged hyphae whether or not they cause the damage. Their direct involvement in the lysis is not proven. Our data suggest that cellulase enzymes present in mulch may be the initial cause of the lysis.

Soon after chipping, we observed eucalyptus mulch "bloom" with hyphomycete fungi, the early colonizers. The most abundant fungi detected in this study by dilution plating methods were Aspergillus spp., Penicillium spp., and Sporothrix spp. Sporothrix spp. is a human pathogen that was frequently isolated from eucalyptus mulch. Aspergillus and Penicillium are common, leafdecay fungi capable of hydrolyzing $\beta$-1,4-glucosidic linkages of

TABLE 6. Avocado root length and root infections associated with mulches and unmulched soils

\begin{tabular}{lccccc}
\hline & \multicolumn{2}{c}{ Root length $(\mathrm{cm})^{\mathrm{z}}$} & & \multicolumn{2}{c}{$\%$ Root infection } \\
\cline { 2 - 3 } \cline { 5 - 6 } Treatment & $\mathrm{I}$ & $\mathrm{II}$ & & $\mathrm{I}$ & $\mathrm{II}$ \\
\hline Mulched trees & & & & \\
1. Mulch surface & $0.00 \mathrm{c}$ & $0.00 \mathrm{c}$ & & $0 \mathrm{~b}$ & $0 \mathrm{~b}$ \\
2. Midmulch & $8.34 \mathrm{bc}$ & $0.16 \mathrm{c}$ & & $0 \mathrm{~b}$ & $0 \mathrm{~b}$ \\
3. Interface & $22.71 \mathrm{ab}$ & $10.24 \mathrm{a}$ & & $4 \mathrm{ab}$ & $0 \mathrm{~b}$ \\
4. Soil $7.5 \mathrm{~cm}$ & $16.70 \mathrm{bc}$ & $3.78 \mathrm{bc}$ & & $12 \mathrm{a}$ & $2 \mathrm{ab}$ \\
5. Soil $15 \mathrm{~cm}$ & $8.80 \mathrm{bc}$ & $3.14 \mathrm{bc}$ & & $8 \mathrm{a}$ & $6 \mathrm{a}$ \\
Unmulched trees & & & & $0 \mathrm{~b}$ & $0 \mathrm{~b}$ \\
6. Surface & $0.00 \mathrm{c}$ & $0.47 \mathrm{c}$ & & $0 \mathrm{~b}$ & $4 \mathrm{ab}$ \\
7. Soil $7.5 \mathrm{~cm}$ & $37.34 \mathrm{a}$ & $6.11 \mathrm{ab}$ & & $4 \mathrm{ab}$ & $0 \mathrm{~b}$ \\
8. Soil $15 \mathrm{~cm}$ & $6.95 \mathrm{bc}$ & $3.70 \mathrm{bc}$ & & $10 \mathrm{a}$ & \\
\hline
\end{tabular}

${ }^{\mathrm{z}}$ Root length is the length of roots (centimeter) recovered from the sample per $100 \mathrm{~g}$ of soil or mulch. Root infections are the percentage of Phytophthora cinnamomi infections occurring on $101-\mathrm{cm}$ root pieces harvested from each sample. Column means followed by the same letter are not significantly different according to analysis of variance and LSD $(P<$ 0.05). Data were transformed (tangent) before analysis (transformed values not shown). I and II refer to samples one and two, respectively. Samples were collected on January 1996 for I and March 1996 for II. cellulose $(1,38)$. Penicillium funiculosum is a biocontrol agent of Phytophthora cinnamomi (18). Control with Penicillium funiculosum is promoted by low $\mathrm{pH}$ potting media, and the most effective isolates of Penicillium funiculosum are the most lytic. These observations are consistent with an enzymatic mechanism of hyphal lysis because cellulase enzymes have low $\mathrm{pH}$ optima $(13,48)$. Hyphomycetes are frequently hyperparasites of pathogenic fungi. As observed in the Ashburner system (10), we also found hyperparasite activity at the interface of mulch and soil (data not shown), although there were no statistical differences in hyperparasitism at any of the soil and mulch depths, suggesting hyperparasitism may not have played an important role in Phytophthora control in this study.

As hyphomycetes use available sugars in the chipped foliage, enzyme systems repressed by glucose are activated to degrade the remaining cellulose and the mulch begins to decompose. Recalcitrant woody tissues with lignin and suberin remain for decomposition by white-rot wood decay fungi (50). Although we did not detect the spores of the white-rot fungi Phanerochaete and Ceraceomyces in agar plate assays, these organisms were abundant, with copious cordons throughout the mulch (Fig. 1). They were also persistent, growing in freshly applied mulch each year. White-rot fungi are potent enzyme producers capable of secreting large quantities of exogenous enzyme systems that break exo- and endo- $\beta$-1,3- and $\beta$-1,4-glucan linkages (25). The enzyme systems of these two white-rot fungi have not yet been studied, but enzymes of the closely related Phanerochaete chrysosporium have been extensively characterized $(17,28)$. Phanerochaete chrysosporium is frequently studied because of its lignolytic ability, but it is also a copious $\beta$-1,3- and $\beta$-1,6-glucanase producer (11). Both of these glucan linkages are found in the polymers forming cell walls of Phytophthora (3).

Enzymes capable of decomposing Phytophthora hyphal walls (P.cinase) were easily detected in mulches; yet, their presence and activity were low or not detected in soil. Although plant materials do produce $\beta$-1,3-linked glucans (callose), this polymer is uncommon in plants. However, $\beta-1,3$-linked glucans are common in the fungal kingdom. Thus, presence of $\beta$-1,3-glucanases in mulch is probably due to microbial attack on other fungi in the mulch. Oomycete fungi are unusual because they contain significant amounts of cellulose in their cell walls. P.cinase detected in our study is most likely analogous to cellulase enzymes commonly found in mulches. We found that microbial activity and P.cinase are highly correlated with carboxymethyl cellulase activity. Because cellulose is an important cell wall constituent of oomycetes, it is likely that mulch cellulases act upon Phytophthora substrates. In this study, Phytophthora cell wall components were also degraded by mulch hydrolases, making the mulch environment unsuitable for Phytophthora because the enzymes in the mulch may destroy or damage the cell walls of the pathogen.

TABLE 7. Correlation coefficients for linear regressions among enzyme activities, microbial activity, and fungal populations

\begin{tabular}{lrrrcc}
\hline & \multicolumn{5}{c}{ Coefficients of correlation $(r)^{\mathrm{y}}$} \\
\cline { 2 - 6 } & \multicolumn{5}{c}{ Fungal } \\
& FDA & CFU & CMCase & Laminarinase & P.cinase \\
\hline FDA & $\ldots$ & 0.738 & 0.770 & 0.669 & 0.512 \\
Fungal CFU & 0.738 & $\ldots$ & 0.669 & 0.512 & 0.594 \\
Phytophthora $^{\mathrm{z}}$ & -0.622 & -0.582 & -0.615 & -0.534 & -0.427 \\
P.cinase & 0.512 & 0.594 & 0.722 & 0.465 & $\ldots$ \\
\hline
\end{tabular}

y All regressions had significant $t$ values at $P<0.001$. FDA is microbial activity assayed by hydrolysis of flourescein diacetate. Fungal CFU is colony forming units of saprophytic fungi. CMCase is enzyme activity detected against carboxymethyl cellulose. Laminarinase is activity detected against laminarin. P.cinase is activity detected against Phytophthora cinnamomi cell walls.

${ }^{\text {z }}$ Phytophthora is total Phytophthora spp. baited from the samples. 
We found root rot caused by Phytophthora to be most extensive in soil layers but undetectable in mulch layers. Neither Phytophthora cinnamomi nor Phytophthora citricola colonized mulch layers and, although their occurrence at the soil-mulch interface was detected, it was less frequent than in soil despite the fact that roots were abundant in the interface region. Although Phytophthora citricola is not a root pathogen of avocado, we recorded its presence in samples because its cell walls also contain cellulose and would be susceptible to the same enzymatic mechanisms we are proposing to control Phytophthora cinnamomi. Cook and Baker (10) noted that the interface between soil and mulch is an area of high microbial activity and antagonism to Phytophthora cinnamomi. It is also the soil layer with the greatest exposure to mulch-generated enzyme systems. Low enzyme activity in soils (poor lytic potential) was correlated with higher Phytophthora levels $(31,35,41)$. Although enzymes are produced heavily in mulch, we found they did not move past the interface into underlying soil. This seems to conflict with other reports in which organic matter increased microbial and enzyme activities in soil $(29,44)$. In this study, mulch was only applied to the soil surface (which was high in clay content), not incorporated in any way except through natural decomposition. Soil hydrolases are easily bound in organic litter layers and will not move in clay soils $(21,43)$. Roots growing in clay soil below mulch may not derive any disease control benefit from enzyme systems above them. However, avocado produces an abundant root system in organic litter layers. This is apparently a preferable place for avocado roots to grow and, thus, avoid the root rot pathogen Phytophthora cinnamomi. Roots growing in decomposing mulch are exposed to active and stabilized enzyme by-products of mulch fungi. Mulch enzyme complexes containing various glucanases may prevent zoospore formation, survival, encystment, or infection due to the lytic potential in the mulch. This study shows that enzymes with the potential to attack components of Phytophthora cell wall polymers are prevalent in eucalyptus mulches and that Phytophthora does not populate these mulch strata. Root health is promoted in mulch layers where the highest enzyme concentrations are detected.

\section{LITERATURE CITED}

1. Abdel-Sater, M. A. 1994. Cellulase activity and succession of fungi in soil amended with sodium chloride, organic matter and Ca-superphosphate. J. Basic Microbiol. 34:283-302.

2. Alef, K., and Nannipieri, P. 1995. Cellulase activity. Pages 345-349 in: Methods in Applied Soil Microbiology and Biochemistry. K. Alef and P. Nannipieri, eds. Academic Press, San Diego.

3. Bartnicki-Garcia, S., and Lippman, E. 1973. Fungal cell wall composition. Pages 229-252 in: CRC Handbook of Microbiology. A. I. Laskin and H. A. Lechevalier, eds. CRC Press, Cleveland.

4. Boehm, M. J., and Hoitink, H. A. J. 1992. Sustenance of microbial activity in potting mixes and its impact on severity of Pythium root rot of poinsettia. Phytopathology 82:259-264.

5. Broadbent, P., and Baker, K. F. 1974. Behaviour of Phytophthora cinnamomi in soils suppressive and conducive to root rot. Aust. J. Agric. Res. 25:121-137.

6. Burns, R. G. 1983. Enzyme activity in soil: Location and a possible role in microbial ecology. Soil Biol. Biochem. 14:423-427.

7. Casale, W. L., Minassian, V., Menge, J. A., Lovatt, C. J., Pond, E., Johnson, E., and Guillemet, F. 1995. Urban and agricultural wastes for use as mulches on avocado and citrus and for delivery of microbial biocontrol agents. J. Hortic. Sci. 70:315-332.

8. Coffey, M. D. 1987. Phytophthora root rot of avocado: An integrated approach to control in California. Plant Dis. 71:1046-1052.

9. Conrad, J. P. 1940. The nature of the catalyst causing hydrolysis of urea in soils. Soil Sci. 50:119-134.

10. Cook, R. J., and Baker, K. F. 1983. The Nature and Practice of Biological Control of Plant Pathogens. The American Phytopathological Society, St. Paul, MN.

11. Copa-Patino, J. L., and Broda, P. 1994. A Phanerochaete chrysosporium $\beta$-D-glucosidase/ $\beta$-D-xylosidase with specificity for (1-3)- $\beta$-D-glucan linkages. Carbohydr. Res. 253:265-275.

12. Costa, J. L., da, S., Menge, J. A., and Casale, W. L. 1994. Investigations on some of the mechanisms by which bioenhanced mulches can suppress
Phytophthora root rot of avocado. Microbiol. Res. 151:183-192.

13. Deng, S. P., and Tabatabai, M. A. 1994. Cellulase activity of soils. Soil Biol. Biochem. 26:1347-1354.

14. Dick, W. A. 1984. Influence of long-term tillage and crop rotation combinations on soil enzyme activities. Soil Sci. Soc. Am. J. 48:569-574.

15. Downer, A. J., and Faber, B. 1999. Weed control problems using greenwaste. Proc. Annu. Weed Sci. Soc. Am., 51st, Anaheim, CA.

16. Downer, A. J., and Hodel, D. R. 2001. The effect of mulching and turfgrass on growth and establishment of Syagrus romanzoffiana (Cham.) Becc., Washingtonia robusta $\mathrm{H}$. Wendl. and Archontophoenix cunninghamiana (H.Wendl.) H. Wendl. \& Drude in the landscape. Sci. Hortic. 87:85-92.

17. Eriksson, K. E. L., Blanchette, R. A., and Ander, P. 1990. Biodegration of cellulose. Pages 89-180. in: Microbial and Enzymatic Degradation of Wood and Wood Components. K. E. L. Eriksson, R. A. Blanchette, and P. Ander, eds. Springer-Verlag, New York.

18. Fang, J. G., and Tsao, P. H. 1995. Efficacy of Penicillium funiculosum as a biological control agent against Phytophthora root rots of azalea and citrus. Phytopathology 85:871-878.

19. Frankenberger, W. T., Jr., and Tabatabai, M. A. 1981. Amidase activity in soils. III. Stability and distribution. Soil Sci. Soc. Am. J. 45:333-338.

20. Gilpatrick, J. D. 1969. Effect of soil amendments upon inoculum survival and function in Phytophthora root rot of avocado. Phytopathology 59:979-985.

21. Harter, R. D., and Stotzky, G. 1971. Formation of clay-protein complexes. Soil Sci. Soc. Am. J. 35:383-389.

22. Hoitink, H. A. J., Inbar, Y., and Boehm, M. J. 1991. Status of compostamended potting mixes naturally suppressive to soilborne diseases of floricultural crops. Plant Dis. 75:869-873.

23. Inbar, Y., Boehm, M., and Hoitink, H. A. J. 1991. Hydrolysis of fluorescein diacetate in sphagnum peat container media for predicting suppressiveness to damping-off caused by Pythium ultimum. Soil Biol. Biochem. 23:479-483.

24. Irwin, J. A. G., Cahill, D. M., and Drenth, A. 1995. Phytophthora in Australia. Austr. J. Agric. Res. 46:1311-1317.

25. Jakucs, E., and Vetter, J. 1992. Comparative studies on the lignocellulose degrading ability of various fungus species. Int. J. Mycol. Lichenol. 5:217-235

26. Joshi, S. R., Sharma, G. D., and Mishra, R. R. 1993. Microbial enzyme activities related to litter decomposition near a highway in a sub-tropical forest of North East India. Soil Biol. Biochem. 25:1763-1770.

27. Kellam, M. K., and Coffey, M. D. 1985. Quantitative comparison of the resistance to Phytophthora root rot in three avocado rootstocks. Phytopathology 75:230-234.

28. Kirk, T. K., and Farrell, R. L. 1987. Enzymatic "combustion": The microbial degradation of lignin 1,2. Annu. Rev. Microbiol. 41:465-505.

29. Kiss, M. D. B., and Radulescu, D. 1978. Soil polysaccharidases: Activity and agricultural importance. Pages 117-147 in: Soil Enzymes. R. G. Burns, ed. Academic Press, New York.

30. Lippman, E., Erwin, D. C., and Bartnicki-Garcia, S. 1974. Isolation and chemical composition of oospore-oogonium walls of Phytophthora megasperma var. sojae. J. Gen. Microbiol. 80:131-141.

31. Malajczuk, N. 1983. Microbial antagonism to Phytophthora. Pages 197218 in: Phytophthora: Its Biology, Taxonomy, Ecology, and Pathology. D. C. Erwin, S. Bartnicki-Garcia, and P. H. Tsao, eds. The American Phytopathological Society, St. Paul, MN.

32. Martens, D. A., and Frankenberger, W. T. 1991. Saccharide composition of extracellular polymers produced by soil microorganisms. Soil Biol. Biochem. 23:731-736.

33. Menge, J. A., Ohr, H. D., Johnson, E. L. V., Campbell, S., Guillemet, F., Grech, N., and Pond, E. 1994. The effect of mulches, gypsum and fungicides on the performance of avocado planted in soil with Phytophthora cinnamomi and Phytophthora citricola. (Abstr.) Phytopathology 84:1103

34. Menyonga, J. M., and Tsao, P. H. 1966. Production of zoospore suspensions of Phytophthora parasitica. Phytopathology 56:359-360.

35. Nesbitt, H. J., Malajczuk, N., and Glenn, A. R. 1979. Effect of organic matter on the survival of Phytophthora cinnamomi Rands in soil. Soil Biol. Biochem. 11:133-136.

36. Newman, E. I. 1966. A method of estimating the total length of root in a sample. J. Appl. Ecol. 3:139-145.

37. Nilsson, T., and Ginns, J. 1979. Cellulolytic activity and the taxonomic position of selected brown-rot fungi. Mycologia 71:170-177.

38. Raper, K. B., and Fennell, D. I. 1977. The Genus Aspergillus. Williams \& Wilkens, Baltimore

39. Schinner, F., and Von Mersi, W. 1990. Xylanase, carboxymethylcellulase and invertase activity in soil: An improved method. Soil Biol. Biochem. 22:511-516.

40. Schnurer, J., and Rosswall, T. 1982. Fluorescein diacetate hydrolysis as a measure of total microbial activity in soil and litter. Appl. Environ. 
Microbiol. 43:1256-1261.

41. Shea, S. R., and Broadbent, P. 1983. Developments in cultural and biological control of Phytophthora diseases. Pages 335-350 in: Phytophthora: Its Biology, Taxonomy, Ecology, and Pathology. D. C. Erwin, S. Bartnicki-Garcia, and P. H. Tsao, eds. The American Phytopathological Society, St. Paul, MN.

42. Sinsabaugh, R. L., Antibus, R. K., and Linkins, A. E. 1991. An enzymic approach to the analysis of microbial activity during plant litter decomposition. Agric. Ecosyst. Environ. 34:43-54.

43. Sinsabaugh, R. L., and Linkins, A. E. 1988. Adsorption of cellulase components by leaf litter. Soil Biol. Biochem. 20:927-932.

44. Tateno, M. 1987. Limitations of available substrates for the expression of cellulase and protease activities in soil. Soil Biol. Biochem. 20:117118.

45. Tsao, P. H. 1964. Effect of certain fungal isolation agar media on Thielaviopsis basicola and on its recovery in soil dilution plates.
Phytopathology 54:548-555.

46. Tsao, P. H., and Oster, J. J. 1981. Relation of ammonia and nitrous acid to suppression of Phytophthora in soils amended with nitrogenous organic substances. Phytopathology 71:53-59.

47. Waksman, S. A. 1922. A method of counting of numbers of fungi in the soil. J. Bot. 7:339-341.

48. Wirth, S. J., and Wolf, G. A. 1992. Micro-plate colourimetric assay for endo-acting cellulase, xylanase, chitinase, 1,3- $\beta$-glucanase and amylase extracted from forest soil horizons. Soil Biol. Biochem. 24:511519 .

49. Wood, T. M. 1991. Fungal cellulase. Pages 491-533 in: Biosynthesis and Biodegradation of Cellulose. C. M. Haigler and P. J. Weimer, eds. Marcel Dekker Inc., New York.

50. Worral, J. J., Anagnost, S. E., and Zabel, R. A. 1997. Comparison of wood decay fungi among diverse lignicolous fungi. Mycologia 89: 199-219. 